\title{
Clostridium difficile 027/NAP1/BI Measurement
}

National Cancer Institute

\section{Source}

National Cancer Institute. Clostridium difficile 027/NAP1/BI Measurement. NCI

Thesaurus. Code C150639.

The determination of the amount of the $027 / \mathrm{NAP} 1 / \mathrm{BI}$ strain of Clostridium difficile species in a biological specimen. 